\title{
Motivational Strategies: The Perceptions of EFL Teachers and Students in the Saudi Higher Education Context
}

\author{
Eman Alshehri (Corresponding author) \\ English Language Institute, King Abdulaziz University \\ PO Box 65058, Jeddah 21556, Saudi Arabia \\ Tel: 966-556-944-677_E-mail: ealshehri@kau.edu.sa
}

\begin{abstract}
Siân Etherington
School of Arts and Media, University of Salford

Crescent House, Greater Manchester M5 4WT, United Kingdom

Tel: 44-779-139-2245Ｅ-mail: s.etherington@salford.ac.uk
\end{abstract}

Received: July 21, 2017 Accepted: August 15, 2017 Published: August 20, 2017

doi:10.5296/ijele.v5i2.11727 URL: https://doi.org/10.5296/ijele.v5i2.11727

\begin{abstract}
Motivation plays a significant role in the L2 learning process, leading many researchers to investigate strategies which can generate and maintain students' motivation in English as a foreign language (EFL) classrooms. However, little research has investigated the perceptions of both EFL teachers and students in the same context. This paper reports an investigation of EFL teacher and student perceptions of motivational strategies in the Saudi Arabian EFL context, aiming to explore potential mismatches. A mixed methods approach was used to collect quantitative and qualitative data in the context of three women's universities. Results indicate the teachers' role in motivating students in EFL classrooms is appreciated by both teachers and students. However, there is a discrepancy in their beliefs about how students should be motivated. Teachers believe strongly that students are mainly motivated by strategies which help achieve academic outcomes. Students, in contrast, appear more motivated by strategies; which relate to actual learning process and promote social aspects of learning, such as participation and interaction. A key implication is that teachers within this
\end{abstract}


context should be encouraged to develop a more balanced view about L2 motivation and motivational strategies, focussing on both academic and social outcomes along with actual learning process.

Keywords: motivational strategies, teacher perceptions, student perceptions, Saudi Arabia, EFL, University preparatory year

\section{Introduction}

There is a clear agreement that second/foreign language motivation (L2 motivation) plays a key role in the second language (L2) learning process (e.g. Gardner, 1985). L2 motivation is needed to help learners expend and persist in their effort in an L2 learning process which might extend over a long period of time. It is believed that,

'without sufficient motivation, even individuals with most remarkable abilities cannot accomplish long-term goals, and neither are appropriate curricula and good teaching enough on their own to ensure student achievement' (Dörnyei, 2005, p.65)

An important aspect of L2 motivation research is the study of motivational strategies used by teachers to enhance students' motivation (e.g. Dörnyei \& Csizér, 1998; Guilloteaux, 2013). This type of research links theory to practice by translating motivational theories into techniques and strategies which could be used by L2 teachers in classrooms. This study examines motivational strategies from the perspectives of both EFL teachers and students in the Saudi context.

\section{Literature Review}

\subsection{Motivation}

Over the last fifty years, a great deal of research has been undertaken in the field of L2 motivation and its relation to the success in L2 learning (e.g. Clément, 1980; Dörnyei, 2005; Gardner, 1979; Gardner 1985; Oxford \& Shearin, 1994; Ushioda, 2009). It is possible to identify key stages of development in motivational research. The early studies of L2 motivation are influenced by the work of Gardner and Lambert $(1959,1972)$ and centre around a social psychological approach. This approach explains attitudes towards and motivation for learning an L2 by integrating the social and individual psychology of learners. A significant development in L2 motivation research occurs in the 1990s when the field expands to incorporate a cognitive and educational view of L2 motivation (e.g., Noels, Clément, \& Pelletier, 1999; Oxford \& Shearin, 1994; Ushioda, 1996). At this stage, research into L2 motivation highlights the teacher's role in motivating students as well as the importance of the learning environment. A number of researchers such as Crookes and Schmidt (1991) and Dörnyei (1994) suggest strategies to be used by teachers to motivate their students in L2 classrooms. 
A further key development in the research into L2 motivation begins when the temporal nature of L2 motivation is addressed by, for example, Williams and Burden (1997), Dörnyei and Ottó (1998) and Ushioda (2001). L2 motivation is consequently viewed as less static, more dynamic and changeable in nature, depending on a number of variables (such as goals) in play during the learning process. As a result of this updated concept of L2 motivation, Dörnyei (2001) develops a comprehensive framework of motivational strategies which EFL teachers can use in L2 classrooms to motivate learners throughout the learning process.

L2 motivation research has more recently been broadened with a development involving the introduction of the role of self and context in understanding L2 motivation, namely in Dörnyei's (2005) model of a 'Motivational Self System' which synthesizes previous research in L2 motivation and reforms it by adding some aspects of the 'self' research in psychology. Dörnyei's model considers the influence of the ideal L2 self (a vision of future L2 self), the Ought to L2 self (a vision of L2 responsibilities and duties) and the language learning environment. Other researchers (Norton, 2000; Ushioda, 2009) move from seeing the motivated self in isolation to the integration of self within a context to understand L2 motivation.

Inevitably, as research perspectives have developed within this area, definitions of motivation have also been modified. Currently, Dörnyei and Ushioda (2011:4) indicate most researchers in the field of motivation share the notion that motivation in general 'concerns the direction and magnitude of human behaviour'. Therefore, motivation is responsible for 'the choice' of doing an action, 'persistence' with doing it and 'effort' invested in doing such action. Dörnyei and Ottó (1998:65) add a further important element in their definition of L2 motivation:

'the dynamically changing cumulative arousal in a person that initiates, directs, coordinates, amplifies, terminates, and evaluates the cognitive and motor processes whereby initial wishes and desires are selected, prioritised, operationalised, and (successfully or unsuccessfully) acted out'.

This definition acknowledges the multidimensional and the dynamic nature of motivation. Highlighting these elements is important for the current study, as this view implies EFL teachers can play a significant role in generating, promoting and maintaining their students' motivation by using effective motivational strategies in their language classroom.

\subsection{Motivational Strategies}

Given the importance of motivation in L2 learning, further investigation into how learners are motivated is needed in order to understand how to initiate and sustain L2 motivation in L2 classroom. Teachers' approaches and actions in increasing their learners' motivation have been termed 'motivational strategies'. Dörnyei (2001, p.28) defines motivational strategies as 'those motivational influences that are consciously exerted to achieve some systematic and enduring positive effect'. This definition assumes teachers can apply some motivational strategies in order to raise learners' motivation.

Motivational strategies have been studied by many researchers and in different contexts, such as Hungary, Iran, Korea, Saudi Arabia, Taiwan, and Turkey (e.g. Alrabai, 2011; Cheng \& 


\section{Mll Macrothink}

Dörnyei, 2007; Guilloteaux, 2013). Most of the research focuses on examining EFL teacher views about a number of motivational strategies (Alrabai, 2011; Cheng \& Dörnyei, 2007; Dörnyei \& Csizér, 1998; Guilloteaux, 2013). Other studies focus on the effectiveness of teachers' use of specific motivational strategies on student motivation, and find a positive relationship between these two variables (Guilloteaux \& Dörnyei, 2008; Moskovsky, Alrabai, Paolini, \& Ratcheva, 2013; Papi \& Abdollahzadeh, 2012). Less research examines the perceptions of students about the effectiveness of particular motivational strategies (Deniz, 2010). In addition, very little research has been conducted to compare the views of both students and teachers towards L2 motivational strategies within the same context (Ruesch, Bown, \& Dewey, 2012). Although a number of studies have examined motivational strategies, there is only a small quantity of research which has been done in the Saudi context (Alrabai, 2011; Moskovsky et al., 2013) and none of this research has been conducted in the context of a preparatory year within a university setting.

The preparatory year at university level in Saudi Arabia is an important one, as students who are admitted to study at university have to successfully complete an intensive English language course before they are able to begin undergraduate programmes. This puts a certain amount of motivational pressure in relation to L2 learning on students in this year.

As Dörnyei and Csizér (1998) highlight, teaching practices which might be seen as motivational in one context can be viewed as less useful in another. Therefore, further investigation into teacher and student perceptions of L2 motivational strategies within the Saudi preparatory year context may provide greater understanding of this important time in students' English learning and development.

\section{Research Questions}

In order to investigate EFL teachers and students' perceptions of motivational strategies in the context of Saudi Arabia, the study posed the following exploratory research questions:

- What are EFL teachers' perceptions about different motivational strategies in the Saudi women's university context? ${ }^{\mathrm{i}}$

- What are EFL students' perceptions about different motivational strategies in the Saudi women's university context?

- In what way do EFL teachers' and students' perceptions of these motivational strategies in this context differ?

\section{Methodology}

\subsection{Participants}

Participants were EFL teachers and students from preparatory year classes in three women's universities in Saudi Arabia, and the age of participants is 18 years old and over. There were 458 participants in total (Teachers: 105, Students: 353). All participants were Arabic speakers. Table 1 shows the number of participants in the different stages of data collection. 


\section{Il Macrothink}

Table 1. Study's Participants

\begin{tabular}{llll}
\hline Instrument & University & EFL teacher & EFL student \\
\hline Exploratory & University A & 2 & 1 \\
interviews & University B & 2 & 2 \\
& University C & 2 & 2 \\
\hline Questionnaire & University A & 87 & 136 \\
& University B & 6 & 109 \\
& University C & 3 & 100 \\
\hline Follow-up interviews & University A & 2 & 1 \\
& University B & 1 & 1 \\
& University C & - & 1 \\
\hline Total & 458 & 105 & 353 \\
\hline
\end{tabular}

\subsection{Instruments}

The study followed a mixed methods approach (Dörnyei 2007; Teddlie and Tashakkori 2009). The instruments consisted of exploratory semi-structured interviews, which fed into the development of teacher and student questionnaires, and follow-up interviews. Thus, the research took a qual-QUAN-qual design (Dörnyei 2007:169).

The initial exploratory interviews were conducted in the participants' place of education or employment. Interviews were conducted individually, face-to-face and recorded. They were conducted in Arabic to allow interviewees to express themselves more clearly, apart from two teachers who preferred to be interviewed in English. Each participant signed an informed consent form translated into Arabic prior to the interview. The average length of each interview was about 30 minutes. Refer to Appendix 1 for interview guidelines. The transcribed interview data was analysed thematically, allowing for the exploration of 'implicit and explicit ideas within the data' (Guest, MacQueen, \& Namey, 2011:10).

In the questionnaire development, main sources of the questionnaire items were the exploratory interviews and the previous literature investigating L2 motivational strategies (e.g. Dörnyei, 2001; Cheng \& Dörnyei, 2007). The questionnaire was piloted both for ease of use and reliability leading to some changes to wording and order of items. After piloting, the final questionnaire consisted of 65 six-point Likert type items, ranging across 10 scales. The scales were multi-item (Dörnyei and Csizér, 2012) and related to the following areas:

- Ideal L2 self

- L2 related values

- Teacher behaviour

- Goals

- Learner autonomy

- Task

- Classroom atmosphere 
- Learner confidence

- Learner group

- Recognise students' effort

Participants were asked to indicate their level of agreement with the items within each scale. A teacher and student version of the questionnaire were distributed. These two forms were similar, with differences only in demographic questions (See Appendices 2 and 3 for teacher and student questionnaire).

The questionnaires were distributed to EFL teachers and students within the three universities. Questionnaires took approximately 20 minutes to complete. Signed informed consent forms were obtained from respondents prior to their completion of the questionnaires.

The follow-up interviews aimed to provide a more in-depth understanding of participants' views about motivational strategies (See the interview guidelines attached in Appendix 4). Interviewed participants had indicated in their questionnaire responses that they would be willing to take part in this phase of the research. The interviews were semi-structured, individual, recorded and took place in the universities' facilities. Interviews lasted between 18 and 45 minutes, and they were conducted in Arabic to best allow participants to express their thoughts and opinions. Purposes of the interviews were explained to the participants and signed consent forms were obtained from them prior to the beginning of interviews.

\subsection{Data Analysis}

Analysis of the questionnaire data took the form of reliability analysis of scales; descriptive statistics to show trends in responses across the two respondent groups; and inferential statistics (Mann Whitney test) to show differences in opinions between the two groups. Results from these analyses are presented and discussed below. Follow-up interview data analysis used thematic analysis to code and then compare teacher and student views.

\subsection{Reliability Analysis}

The Cronbach Alpha $(\alpha)$ coefficient of the questionnaire scales ranges from 0.6 to 0.80 ; within the range of accepted reliability scores (Dörnyei, 2003; Pallant, 2010).

Internal reliability of the scales was further checked using mean inter-item correlation as recommended by Briggs and Cheek (1986) and found to be between 0.2 and 0.4 (within acceptable limits). The table presenting both Cronbach Alpha $(\alpha)$ and mean inter-item correlation of the ten scales is provided in appendix 5.

\section{Results}

This section will present the quantitative and qualitative data.

\subsection{Descriptive Results}

\subsubsection{Teacher Perceptions}


Table 2 displays the views of teachers towards motivational strategies ${ }^{\mathrm{ii}}$.

Table 2. Teacher Perceptions about Motivational Strategy Scales

\begin{tabular}{lll}
\hline Scale & $M d n(I Q R)$ & $M(S D)$ \\
\hline Learner confidence & $5.71(0.63)$ & $5.60(0.35)$ \\
Classroom atmosphere & $5.71(0.57)$ & $5.58(0.37)$ \\
Teacher behaviour & $5.67(0.65)$ & $5.57(0.37)$ \\
Ideal L2 self & $5.50(1.00)$ & $5.46(0.55)$ \\
Task & $5.40(0.80)$ & $5.42(0.43)$ \\
Goals & $5.40(0.80)$ & $5.36(0.50)$ \\
Learner group & $5.33(0.83)$ & $5.35(0.49)$ \\
Recognise students' effort & $5.33(0.67)$ & $5.25(0.48)$ \\
L2 related values & $5.08(0.83)$ & $5.09(0.58)$ \\
Learner autonomy & $4.20(1.20)$ & $4.21(0.86)$
\end{tabular}

The top three scales, in Table 2, are Learner confidence, Classroom atmosphere and Teacher behaviour. Learner autonomy is the scale which shows the lowest mean values (i.e. teachers agreed less strongly). Overall, the descriptive results suggest the teachers' awareness of their influence on student motivation and the influence of using motivational teaching practices. However, they show their greatest agreement with teacher-led motivational strategies and least agreement with student-centred motivational strategies.

\subsubsection{Student Perceptions}

As is the case with teachers, students hold a high level of agreement with all the scales.

Table 3. Student Perceptions about Motivational Strategy Scales

\begin{tabular}{lll}
\hline Scale & $M d n(I Q R)$ & $M(S D)$ \\
\hline Ideal L2 self & $5.50(0.75)$ & $5.43(0.55)$ \\
Classroom atmosphere & $5.43(0.71)$ & $5.36(0.49)$ \\
Learner confidence & $5.43(0.57)$ & $5.36(0.48)$ \\
Teacher behaviour & $5.33(0.67)$ & $5.32(0.49)$ \\
Recognise students' effort & $5.17(0.67)$ & $5.11(0.55)$ \\
Learner autonomy & $5.20(0.80)$ & $5.09(0.63)$ \\
Task & $5.20(0.80)$ & $5.08(0.58)$ \\
Goals & $5.20(0.60)$ & $5.06(0.59)$ \\
L2 related values & $5.00(0.73)$ & $4.94(0.64)$ \\
Learner group & $5.00(0.83)$ & $4.89(0.62)$ \\
\hline
\end{tabular}


The mean values of the motivational scales, shown in Table 3, reveal that the most strongly agreed with scale is Ideal L2 self. Classroom atmosphere and learner confidence are among the top three scales.

From Table 3, it can be seen that strategies which are most motivating for students relate to how they picture themselves and how they feel in the classroom in general, rather than what they do in the classroom. The Task, Goals and Teacher behaviour are more specific to the class content, what is learned and how and these are not mentioned in the top three categories. Students also appear to find these motivating, but not as motivating as the more personal and interpersonal areas, mentioned above. The scales which students feel are the least motivating relate to instrumental, integrative values, and learner group. These scales include strategies which are not related to classroom itself and are about class organisation rather than the content.

\subsection{Inferential Statistics}

A Mann-Whitney test was used to assess teacher and students scores in order to determine if there was a significant difference between the groups. As recommended by Thompson (2002), the effect size is also reported here.

Table 4 shows the results from the Mann-Whitney test comparing teachers and students in terms of their views towards the motivational scales.

Table 4. Mann-Whitney Test Results of Difference between Teachers and Students- Scales and Items

\begin{tabular}{|c|c|c|c|c|c|c|}
\hline \multirow{2}{*}{ Scales } & \multicolumn{3}{|c|}{ Median (Mean rank) } & \multirow{2}{*}{$\begin{array}{ll}\text { M-W U } & \mathrm{Z} \\
& \text { score }\end{array}$} & \multirow{2}{*}{ P-value ${ }^{1}$} & \multirow{2}{*}{$\begin{array}{l}\text { Effect } \\
\text { size }\end{array}$} \\
\hline & No. & Teachers & No. Students & & & \\
\hline Ideal L2 self & 96 & $\begin{array}{l}5.50 \\
(229)\end{array}$ & $345 \begin{array}{l}5.50 \\
(219)\end{array}$ & $15785.00-0.714$ & 0.475 & 0.03 \\
\hline L2 related values & 96 & $\begin{array}{l}5.08 \\
(238)\end{array}$ & $345 \begin{array}{l}5.00 \\
(216)\end{array}$ & $14898.00-1.511$ & 0.131 & 0.07 \\
\hline $\begin{array}{l}\text { Recognise students' } \\
\text { effort }\end{array}$ & 96 & $\begin{array}{l}5.33 \\
(245)\end{array}$ & $345 \begin{array}{l}5.17 \\
(214)\end{array}$ & $14249.50-2.102$ & 0.036 & 0.10 \\
\hline Teacher behaviour & 96 & $\begin{array}{l}5.67 \\
(273)\end{array}$ & $345 \begin{array}{l}5.33 \\
(207)\end{array}$ & $11614.00-4.506$ & $0.000 *$ & $0.21^{\wedge}$ \\
\hline Goals & 96 & $\begin{array}{l}5.40 \\
(268)\end{array}$ & $345 \begin{array}{l}5.20 \\
(208)\end{array}$ & $12005.50-4.147$ & $0.000 *$ & $0.20^{\wedge}$ \\
\hline
\end{tabular}




\begin{tabular}{|c|c|c|c|c|c|c|}
\hline Task & 96 & $\begin{array}{l}5.40 \\
(278)\end{array}$ & $345 \begin{array}{l}5.20 \\
(205)\end{array}$ & $11104.50-4.972$ & $0.000 *$ & $0.24^{\wedge}$ \\
\hline Classroom atmosphere & 96 & $\begin{array}{l}5.71 \\
(267)\end{array}$ & $345 \begin{array}{l}5.43 \\
(208)\end{array}$ & $12126.00-4.037$ & $0.000 *$ & $0.19^{\wedge}$ \\
\hline Learner confidence & 96 & $\begin{array}{l}5.71 \\
(275)\end{array}$ & $345 \begin{array}{l}5.43 \\
(206)\end{array}$ & $11383.00-4.711$ & $0.000 *$ & $0.22^{\wedge}$ \\
\hline Learner group & 96 & $\begin{array}{l}5.33 \\
(294)\end{array}$ & $345 \begin{array}{l}5.00 \\
(201)\end{array}$ & $9591.50 \quad-6.334$ & $0.000 *$ & $0.30^{\wedge}$ \\
\hline Learner autonomy & 96 & $\begin{array}{l}4.20 \\
(116)\end{array}$ & $345 \begin{array}{l}5.20 \\
(250)\end{array}$ & $6503.00 \quad-9.143$ & $0.000 *$ & $0.44^{\wedge}$ \\
\hline
\end{tabular}

Note: Total no. of participants $=441($ Teachers $=96$, Student $=345) .{ }^{1}$ of scales $=p \leq .005$ (adjusted using Bonferroni correction .05/10). ${ }^{*}=$ significant difference. ${ }^{\wedge}=$ small effect size; $\stackrel{\wedge}{=}$ medium effect size.

Generally, the median values indicate teachers agree more strongly than students with most of the motivational scales and items. This may be due to the teacher role and their awareness of what works in the classroom and their understanding of the need to motivate students in L2 learning. Students also agree overall with the motivational scales and items, but less strongly.

\subsubsection{Similarities}

When comparing teachers' and students' views of motivational scales, results show that there are similarities in three areas:

- Ideal L2 self

- L2 related values

- Recognising student efforts

Similarities here could be because students feel much more involved in these areas. In addition, as these scales relate to them personally and they have an active role, they believe they are motivational.

In line with these quantitative findings, interviews showed similarities in teachers and students views about the examined motivational scales. For example, both groups considered L2 values (integrative and instrumental) to be motivating factors. For instance, Teacher A asserted that students are motivated to learn English for instrumental reasons:

Most of the students are motivated for practical reasons, to get a job or to continue studying and complete their studying. (Teacher A: r37, TI-C2) iii $^{\text {in }}$

Like teachers, all students expressed strongly their need for English for instrumental reasons, which included getting a job and communicating with people when travelling. However, students also talked about other instrumental reasons that did not relate to their future career or their academic achievements. Students E and F talked about reasons such as accessing 
particular books and websites written in English but not specifically for English language learning purposes. For example:

[English is] not only for studying, but if you want to browse internet or you want to talk to someone abroad. (Student E: r80, ST-C2)

When we go camping abroad, we need English to communicate with other people. I also read books in English, most of my books are about make up, but they are all in English. (Student F: r128, ST-C2)

It can be seen that although some similarities exist in the two parties, differences do appear in their views about the examined motivational themes. These differences emerge when students speak about their motivation to learn English for personal interest and being exposed to L2 culture, such as using the internet, reading books and communicating with L2 speakers on a social level.

\subsubsection{Significant Differences - small Effect}

There are significant differences with small effect size in five of the scales which are:

- Teacher behaviour

- Goals

- Task

- Classroom atmosphere

- Learner confidence

Though both students and teachers agree with these scales in general, results indicate that teacher beliefs are stronger in terms of how motivating these strategies are. This is possibly due to teachers having more experience of setting up the basic conditions of the classroom in terms of atmosphere and organisation and that they are more aware of the work involved in these areas, since they will consider these strategies when planning and delivering their lessons.

During the interviews, both teachers and students expressed their beliefs in the motivational role of the examined scales. For example, they appear to agree on the importance of breaking up the routine of class by using different tasks, to prevent boredom and maintain students' interest. Teacher A stated:

When we break up the routine in the class, students become more motivated and they cooperate to do their work. Using different forms of presentation to present tasks is important in the classroom. The teacher should set up tasks to be done individually, in pairs, or in groups... We should use a variety of task presentations to maintain students' motivation. (Teacher A: $r 41, T I-C 2)$

Interviewed students agreed with their teachers, Student $\mathrm{C}$ said: 
Breaking up the routine of the class is important. If the class always follows the same presentation format, this will be boring. If the teacher uses different forms of presentation, this will be better. (Student C: r41, ST-C2)

Students provide more detail about how the tasks and their content can be motivating. In their views, tasks should involve relevant topics to their everyday life, interaction, participation, discussion and involvement. For instance, Student $\mathrm{C}$ stated that teachers should discuss social topics in L2 classes, and then argued for the need to involve students in the class by use of discussion of social topics to encourage interaction:

When she speaks and discusses topics with us, she can discuss social topics... the most important thing is to have interaction in the class, not only to have a lesson and no more, and then just homework, I want something more. (Student C: r16, ST-C2)

It can be seen here that students give much more importance to the social aspects surrounding language learning. This is echoed in various instances throughout the qualitative data, when participants spoke about their views of the motivational scales investigated. For instance, when students explained how teacher behaviour was motivational, they referred to the strategies which relate to the social aspects of L2 leaning process.

Student E spoke about the effects of ways in which the teacher deals with students:

The most important thing is the way the teacher deals with the student. The teacher should deal with students in a good way. When there is good teacher behaviour, we will like the subject, we will like the class, and you will wish to have the class. (Student E: r96, ST-C2)

Teachers talk about teacher behaviour in terms of how they motivate their students to learn, work hard, study and improve their L2. For example, Teacher A talks about the importance of taking on a caring role, such as a big sister, to encourage their learning:

The teacher should be like their big sister. This is necessary, they should feel that they are close to you. If they do not like their teacher, they will not learn. (Teacher A: r48, TI-C2)

Teacher D explained how caring about students and speaking with them individually encourage them to study hard:

They will improve when you show them that you care about them, even if the student at the beginning is careless, she will care more later. She will feel shy when the teacher cares about her, so she reacts positively, she will care and try harder. I think the teacher has a big role in motivating students. (Teacher D: r131, TI-C2)

As can be seen so far, participants appear to agree on the motivational role of the examined scales, but when the participant responses are studied more closely, the drivers behind the use of such strategies, which usually represent their underlying beliefs, are different. In general, 
teachers appear to relate L2 motivation with the outcomes being achievement based. Students lean towards social and interactive motivators involving feeling relaxed, and enjoying participation in the class.

\subsubsection{Significant Differences - medium Effect Size}

Significant differences between teachers and students with medium effect size are found in two scales which are:

- Learner group

- Learner autonomy

'Learner Group' is more strongly favoured by teachers than students. It could be suggested here that teachers are more in favour of strategies relating to group organisation, which is classroom-based, within their control and is a technique they will be comfortable and familiar with.

The interview data provides some clues as to why 'learner group' is less preferred by students. Although both groups agreed that creating a cohesive learner group is a motivating teaching practice, the main difference appeared when they talked about the strategy of 'group work'. All teachers insisted that group work is effective to create cohesive groups and motivate students. For example, Teacher A said:

Group work promotes cohesive group work, as students will get to know each other. (Teacher A: r45, TI-C2)

When talking about grouping students, the technique mentioned is based on students' level of English. Teacher D stated:

We should also change their group because if they sit in a specific place, what happens is, the strong [in terms of language level] students will overshadow the weak students, and the weak students will depend on the strong students, and then what happens is that the weak students will lack confidence. It is true that it is important to have a strong and weak student in a group because they can help each other, but this depends on the type of the task and the goal of the task. (Teacher D: r129, TI-C2)

Teachers appear to believe that the benefits of changing the composition of groups relate to the academic achievement of each student, rather than improving group dynamics, social interaction and subsequently student motivation.

For students, however, it is social interaction and group dynamics which are paramount in their views about the difficulties of group work. Student $\mathrm{C}$ pointed to the lack of co-operation in group work:

I do not like group work because I do not get along with students. I do not know why. Each one wants something, and then the group does not work well, so what is the point of doing group work...In my own view, I do not like group work. If we can choose our group members, this might be 
better... At the beginning, I tried to do group work, but eventually I began to hate it. I feel that doing my work individually is better. (Student C: $r 44$, $S T-C 2)$

Student $\mathrm{F}$ reported the lack of cooperation between group members:

I do not like group work because some students do not do their work. I have tried group work several times, and once they [other students in the group] let me do all the work alone...They are not cooperative, and some are careless. (Student F: r143, ST-C2)

The Learner autonomy scale is favoured by students more than teachers, and is the only scale where students agree more with a scale than teachers. Learner autonomy suggests involvement and participation from the students in the learning process, and these social aspects of learning appear to be very appealing to students. Teachers may be hesitant to relinquish their control as they feel it would lead to academic underachievement of their students.

Qualitative data indicate both groups' agreement on the motivational role of strategies related to learner autonomy, which includes (in their opinion) using technology resources and programmes designed for L2 learning. Teachers and students also agree that learner 'autonomous work' should be directed by teachers. Teachers focus more on the idea of self study which helps students to progress in L2 learning. For example, Teacher A said:

We encourage them to learn by themselves, and this is important. We always tell them that English can be learned by self-study, and the English teacher should be a guide who directs students to study or learn English ...We help them by telling them the ways that they can use for self-study. (Teacher A: r40, TI-C2)

Students, on the other hand, see autonomy as guided or optional homework:

She should tell us what to do, and we will do it. She should give us the keys so we can do it. (Student C: r40, ST-C2)

She [the teacher] can say 'read a book at home and then we will discuss it in the next class'... This is not like homework, it is optional, in this way they will like it. (Student F: r142, ST-C2)

Students' views about learner autonomy suggests the only autonomy they are familiar with is self study directed by teachers. However, the quantitative data shows that when students are presented with options about what autonomy could involve, they strongly agreed with the items which allowed them involvement and choices in their learning processes.

Based on an analysis of the quantitative and qualitative data, it appears that there are some discrepancies between teacher and student perceptions about motivational strategies. The motivational scales teachers agreed more strongly with are related to how such strategies will meet the academic outcomes for students. They agreed more strongly with strategies which 
are teacher-led, task and classroom-based and involve the organisation and delivery of the subject. This is probably due to teachers' greater focus on students' academic outcomes in terms of grades and exams and their delivery of the curriculum. In contrast, the learners seem to favour strategies which are related to the social aspects of learning, and those which promote participation, interaction, involvement, as well as use of L2 to communicate with L2 speakers beyond the classroom.

\section{Discussion}

The findings show that both teachers and students are in strong agreement in terms of the teacher role in motivating students. Teachers appear to value their role in motivating their students, and students also perceive this role to be significant in motivating them in L2 classroom. The teachers' role in motivating their students is documented extensively in the literature (e.g., Brophy, 2010; Chamber, 1999; Dörnyei, 2001). Other studies have shown the positive relationship between teachers' use of motivational strategies and enhancing student motivation (e.g., Guilloteaux \& Dörnyei, 2008; Moskovsky et al., 2013).

However, in the context of this study, differences in their beliefs are also apparent and point to clearly distinguishable teachers' and students' understanding of L2 motivation, and strategies which could contribute to it. The following sections provide discussion of their different perceptions.

\subsection{Teacher Perceptions}

Teacher views towards motivational strategies represent their underlying beliefs about L2 motivation, valuing academic achievement and future learning outcomes. Teachers tend to favour motivational strategies which focus on future academic outcomes for students; when considering the process it is with this end result in mind.

To further illustrate the findings, it may be useful to imagine a scale indicating teacher and student perceptions towards motivational strategies and their understanding of what contributes to L2 motivation. As shown in Figure 1, on one side of the scale are the academic aspects of motivation and on the other are the social aspects of motivation. The size of the four elements in the figure has been generated from the findings of both quantitative and qualitative data. 


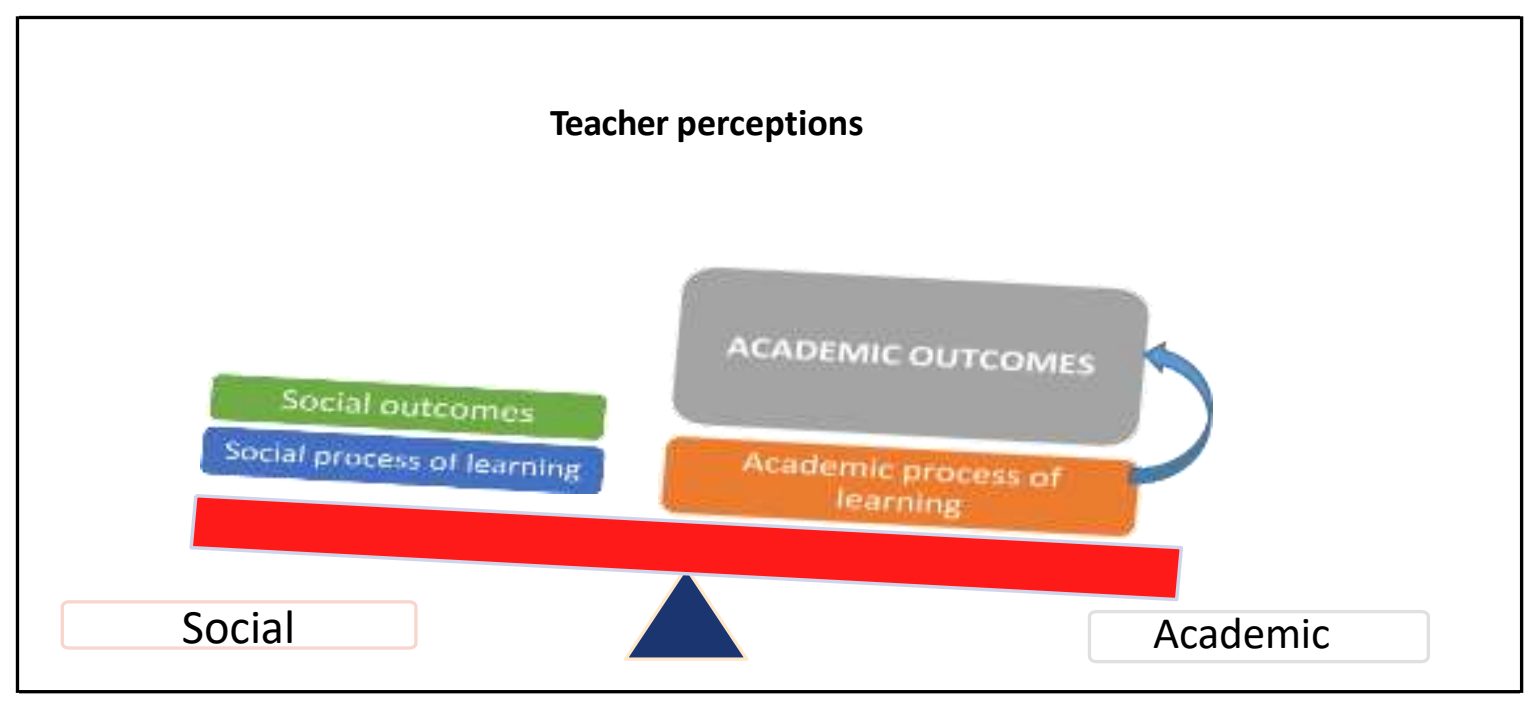

Figure 1. Teacher Perceptions about Motivational Strategies

From Figure 1, it can be seen that teachers' beliefs lie much more strongly on the side of academic rather than social aspects of motivational strategies. The two areas in terms of academic achievement are outcomes and processes, with the outcomes being the most influential for teachers. The learning process, in terms of teachers' views, are linked to the outcomes which determine the motivational strategies used during the learning process.

On the social side of the scale, the outcomes and learning processes are present, but are given much less importance by teachers. This result may be explained by the fact related to the context of the study, as one of the main objectives of the preparatory year in the participating universities is to improve the English level of students to at least intermediate level before starting their university study. Students also are assessed by the end of this year to check their level in English and this determines if they will start their undergraduate study or continue studying English. Being aware of this, EFL teachers seem to focus on motivational strategies which facilitate the achievement of such outcomes.

These results also suggest that teachers tend to concentrate on the future academic outcomes which relate to student progression in L2 learning. This view influences their beliefs about motivational strategies, as they tend to favour the strategies which lead to academic and professional achievement. Previous research has revealed that motivational strategies related to 'increasing learner confidence' and 'presenting tasks in a motivational way' are among the top five most used motivational strategies in Saudi Arabia (Alrabai, 2011), and are also perceived as important in Hungary, Taiwan, and South Korea (Cheng \& Dörnyei, 2007; Dörnyei \& Csizér, 1998; Guilloteaux, 2013).

This result is in accordance with Dörnyei's $(2005,2009)$ idea about his L2 Motivational Self System, as he suggests that L2 learning experience would 'hopefully' positively affect student future-self guides. In teachers' views, these self guides appear to be instrumental and relate to 'ought-to L2 self' as they seem to favour academic and professional outcomes, such as succeeding in exams and finding jobs. 


\section{Ml Macrothink}

International Journal of English Language Education

ISSN 2325-0887

2017, Vol. 5, No. 2

However, the majority of studies which have examined the role of ought-to L2 self, indicate that 'ought-to L2 self' has a weak connection to student motivation (e.g., Csizér \& Kormos, 2009; Dörnyei \& Chan, 2013; Taguchi et al., 2009). In other studies, 'ought-to L2 self' does not appear as a construct of L2 motivation (Csizér \& Lukács, 2010; Lamb, 2012). While here the teacher data indicate that teachers value the role of 'ought-to L2 self' in motivating students, students perceptions seem to favour Ideal L2 self related strategies as more important for them.

\subsection{Students'Perceptions}

One of the major findings of this study is that the students' views about motivational strategies reflect their underlying beliefs about motivation and that these beliefs are set within a social perspective on language learning. Their motivation seems to be influenced, in the main, by social processes of learning. The social outcomes of learning also seem to affect their motivation in a positive way. In the quantitative data, students tend to express more agreement with motivational strategies which relate to the social aspects of learning, and those which promote participation, interaction, involvement, as well as use of L2 to communicate with L2 speakers.

Figure 2 shows students' understanding of the sources contributed to L2 motivation.

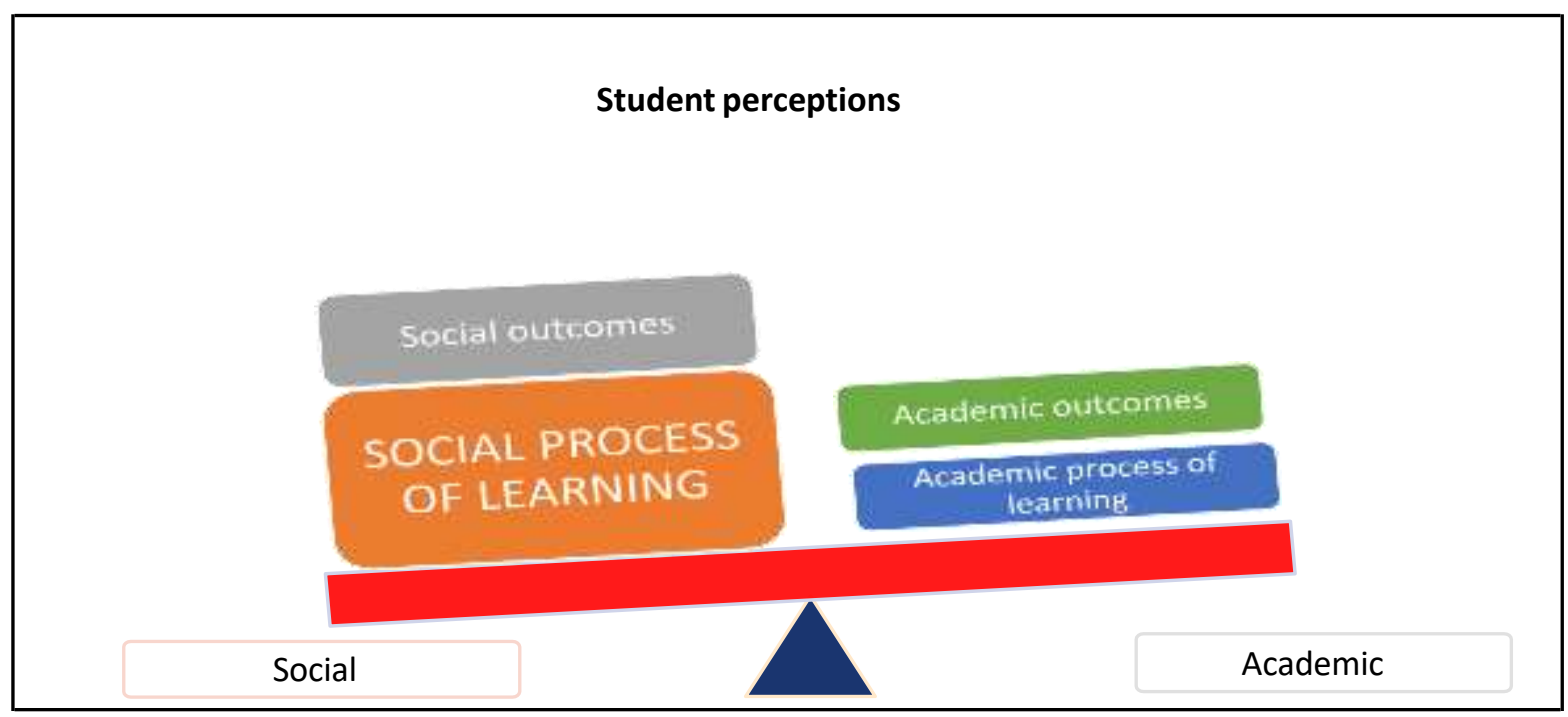

Figure 2. Student Perceptions about Motivational Strategies

As it appears in Figure 2, the student scale contains the same headings and elements as the teachers, but the weighting is different, with students clearly favouring the opposite side of the scale from teachers. Students are more in favour of the social than the academic aspects of motivational strategies. Most important for students is the process of learning, which promotes social aspects of learning such as participation, interaction and involvement. This process of learning could be motivating on its own and it does not need to be linked to future outcomes. The future outcomes are on this side of the scale too, as it can be seen by the size that they are less important for students than the process, though still more valued than the academic side of the scale. 
These findings indicate that students recognise the role their learning experience in class plays in motivating them, and the use of motivational strategies which relate to this area. This is consistent with a number of previous studies which found that L2 learning experience is one of the strongest motivators for L2 students (e.g., Csizér \& Kormos, 2009; Islam et al., 2013; Lamb, 2012; Papi, 2010).

A possible explanation for these results in terms of student views is that learner motivation stems from L2 learning experience itself, rather than internal or external reasons or future outcomes. Dörnyei (2009, p.29) suggests that 'for some language learners the initial motivation to learn a language does not come from internally or externally generated self images, but rather from successful engagement with the actual language learning process'.

This correlate with Lamb's (2012) findings which show that the strongest motivator for students is L2 learning experience, while Ideal L2 self has little importance in motivating students. Lamb (2012) suggests that studying English as a compulsory subject with a fixed timetable could explain this finding, since student motivation for learning English is likely to relate more to the immediate context of language learning than to their future self-visions. The value of social process of learning which relate to the present time could indicate the role of the 'actual self' (Higgins, 1987) in motivating students. Students appear to be more motivated by the strategies which contribute to make the learning interesting and enjoyable in the classroom, and help them to use English outside classroom.

Another salient finding is that students tend to favour social outcomes, such as the use of L2 when travelling abroad, the use of L2 to communicate with L2 speakers, to use the internet and to read books written in English. The benefits of L2 acquisition for students are much more rooted in the social sphere. This could be considered an instrumental reason for L2 learning, an idea supported by some studies which examine the motivation of students in Saudi Arabia (Al-Shammary, 1984; Moskovsky \& Alrabai, 2009). However, students' motives for learning English in this study seem to relate more to the 'Ideal L2 self' than only to instrumental motivations, as the Ideal L2 self includes the instrumental motives which have been internalised (Dörnyei, 2005, p.103) and also has a "promotion focus" which means it is related to hopes, concerns, aspirations, advancements, growth, and accomplishments (Higgins, 1998). This result then indicates that students strongly value motivational strategies which relate to promoting their visions of their future Ideal L2 self. This finding corroborates with previous research which validates the role of Ideal L2 self in motivating students in different contexts (e.g., Islam et al., 2013; Ryan, 2009; Taguchi et al., 2009) among which is the context of Saudi Arabia (Al-Shehri, 2009). It seems possible that this result is due to a number of factors, including the increased use of English in a globalised world (Crystal, 2003), and the use of English as an international language of communication (Yashima, 2002). Another factor could be the desire to pursue a 'bicultural identity' which involves international and local identity, which represents a dynamic process of motivation (Lamb, 2004). English is not associated with particular communities, but with international culture involving technological revolution, travel and 'icons of fashion, sport and music' (Lamb, 2004, p. 3). The advancements in technology, and in particular social technology, could have a key role in shaping the identity and motivation of L2 learners, as they have access to a wide 
range of authentic resources and they interact using English as a Lingua Franca (Stockwell, 2013).

All these factors which relate mainly to globalisation and the advancements of social technology could influence student motivation to learn English, since they tend to favour future outcomes which are related to Ideal L2 self rather than Ought-to L2 self of the L2 Motivational Self System (Dörnyei, 2005).

To recap, Figures 1 and 2 show that the perceptions of teachers and students are distributed in contrasting ways even though all four areas feature for all participants. Ideally, in L2 classroom a balance between these areas should be achieved in order to maximise student motivation in L2 learning.

\section{Conclusions}

The findings of the study can add substantially to our understanding of L2 motivation from the perspectives of both EFL teachers and students. In relation to Dörnyei's (2005) conceptualisation of L2 motivation, teachers' perceptions of motivational strategies here clearly relate to the construct of 'ought-to L2 self' in that they strongly agreed with motivational strategies which relate to academic outcomes and see the process as a means to reach such outcomes, viewing motivation as an achievement- oriented process. Students' beliefs, on the other hand, are more related to the construct of 'L2 learning experiences' and to 'Ideal L2 self'. Currently, Dörnyei's (2005) conceptualisation features these three components of L2 motivation equally; however, this study supports more recent findings (e.g., Csizér \& Kormos, 2009; Dörnyei \& Chan, 2013; Taguchi et al., 2009) that the area of 'ought-to L2 self' is much less motivating for students compared with 'L2 learning experience' and 'Ideal L2 self'. This indicates that these latter components of L2 motivation might have a key role in promoting student motivation rather than the 'ought-to L2 self'. This finding has some implications for EFL teachers. In relation to students in preparatory year, English is not just about getting through the examinations, but even for these students has wider, social and international value.

A further implication is that the 'L2 learning experience' can be considered a stand-alone motivating factor which does not necessarily serve to reach the future-self outcomes, although it may contribute to building ideal or ought-to future selves. The importance of L2 learning experience for students seems to highlight the need to integrate context and motivation in a holistic way to examine the development of L2 motivation by considering the complex interactions between students and their context. This approach has been emerging in theoretical developments of exploring motivation in educational psychology (e.g., Järvelä, 2001), and in language learning (e.g., Norton, 2000; Ushioda, 2009). The value of L2 learning experience which involves the learning process in the classroom could also indicate the role of the 'actual self' (Higgins, 1987) in motivating students and, which is a missing part of the L2 Motivational Self System (Dörnyei, 2005, 2009).

It is proposed therefore that Dörnyei's $(2005,2009)$ L2 Motivational Self System should be 
revisited to identify the role of each component in motivating students; perhaps there should be acknowledgement to the limited role of 'ought-to L2 self' in motivating students, and future consideration of the role of the actual self in L2 motivation.

The study presented in this paper has some limitations. The number of scales used meant that the study covered a broad area of strategies; consideration of fewer scales could have allowed more focussed answers. The current investigation is also limited in the application of its findings to other contexts. The participants of this study were all female and in the context of higher education in Saudi Arabia. The findings, therefore, are not representative of the beliefs of teachers and students in other contexts. Nevertheless, they serve to usefully develop our understandings of motivations of participants in a key educational setting.

The results of this study suggest a number of future research directions. In the context of Saudi Arabia, further investigations are needed to examine the discrepancy between teacher and student perceptions towards the motivational power of teaching practices.

At a theoretical level, deeper understanding of L2 motivation would arise from longitudinal research to examine the internalisation of instrumental motivation for L2 learning. Studying this process of internalisation could broaden the understanding of L2 motivation by revealing the way in which external instrumental motivation develops into internal (Ushioda 2012). A final suggestion for future research would be to study the role of actual self in motivating students, in terms of what students need in everyday language classroom to enhance their motivation.

\section{References}

Al Asmari, A. R. (2013). Practices and prospects of learner autonomy: Teachers' perceptions. English Language Teaching, 6(3), 1-11. Retrieved from http://www.ccsenet.org/

Alrabai, F. A. (2011). Motivational instruction in practice: Do EFL instructors at King Khalid University motivate their students to learn English as a foreign language? Arab World English Journal, 2(4), 257-285. Retrieved from http://www.awej.org/

Al-Shammary, E. (1984). A study of Motivation in the learning of English as a foreign language in intermediate and secondary schools in Saudi Arabia. (Unpublished $\mathrm{PhD}$ thesis), Indiana University, Indiana.

Al-Shehri, A. S. (2009). Motivation and vision: The relation between the ideal L2 self, imagination and visual style. In Z. Dörnyei \& E. Ushioda (Eds.), Motivation, language identity and the L2 self (pp. 164-171). Bristol: Multilingual Matters.

Briggs, S. R., \& Cheek, J. M. (1986). The role of factor analysis in the development and evaluation of personality scales. Journal of Personality, 54(1), 106-148.

Brophy, J. (2010). Motivating students to learn (3rd ed.). New York: Routledge. 


\section{$\triangle$ Macrothink}

Chambers, G. N. (1999). Motivating language learners. Clevedon: Multilingual Matters.

Cheng, H., \& Dörnyei, Z. (2007). The use of motivational strategies in language instruction: The case of EFL teaching in Taiwan. Innovation in Language Learning and Teaching, 1(1), 153-174.

Clément, R. (1980). Ethnicity, contact and communicative competence in a second language. In H. Giles, W. P. Robinson, \& P. M. Smith (Eds.), Language: Social psychological perspectives (pp. 147-177). Oxford: Pergamon.

Crookes, G., \& Schmidt, R. W. (1991). Motivation: Reopening the research agenda. Language Learning, 41(4), 469-512.

Crystal, D. (2003). English as a Global Language (2nd ed.). Cambridge: Cambridge University Press.

Csizér, K., \& Kormos, J. (2009). Learning experiences, selves and motivated learning behaviour: a comparative analysis of structural models for Hungarian secondary and university learners of English. In Z. Dörnyei \& E. Ushioda (Eds.), Motivation, language identity and the L2 self (pp. 98-119). Bristol: Multilingual Matters.

Csizér, K., \& Lukács, G. (2010). The comparative analysis of motivation, attitudes and selves: The case of English and German in Hungary. System, 38(1), 1-13.

Deniz, S. (2010). Student teachers' evaluation of the motivational strategies used in foreign language teaching. Social behaviour and personality, 38(9), 1269-1286.

Dörnyei, Z. (1994). Motivation and motivating in the foreign language classroom. Modern Language Journal, 78(3), 273-284.

Dörnyei, Z. (2001). Motivational strategies in the language classroom. Cambridge: Cambridge University Press.

Dörnyei, Z. (2003). Questionnaires in second language research: construction, administration, and processing. Mahwah, New Jersey: Lawrence Erlbaum Associates.

Dörnyei, Z. (2005). The psychology of the language learner: Individual differences in second language acquisition. Mahwah, New Jersey: Lawrence Erlbaum Associates.

Dörnyei, Z. (2007). Research methods in applied linguistics: Quantitative, qualitative and mixed methodologies. Oxford: Oxford University Press.

Dörnyei, Z. (2009). The L2 Motivational Self System. In Z. Dörnyei \& E. Ushioda (Eds.), Motivation, language identity and the L2 self (pp. 9-42). Bristol: Multilingual Matters.

Dörnyei, Z., \& Chan, L. (2013). Motivation and vision: An analysis of future L2 self images, sensory styles, and imagery capacity across two target languages. Language Learning, 63(3), 437-462.

Dörnyei, Z., \& Csizér, K. (1998). Ten commandments for motivating language learners: Results of an empirical study. Language Teaching Research, 2(3), 203-229. 
Dörnyei, Z., \& Csizér, K. (2012). How to design and analyze surveys in SLA research? In A. Mackey \& S. Gass (Eds.), Research methods in second language acquisition: A practical guide (pp. 74-94). Malden, MA: Wiley-Blackwell.

Dörnyei, Z., \& Ottó, I. (1998). Motivation in action: A process model of L2 motivation. Working Papers in Applied Linguistics, 4(1), 43-69.

Dörnyei, Z., \& Ushioda, E. (2011). Teaching and researching motivation (2nd ed.). Harlow: Pearson Education Limited.

Gardner, R. C. (1979). Social psychological aspects of second language acquisition. In H. Giles \& R. St. Clair (Eds.), Language and social psychology (pp. 193-220). Oxford: Basil Blackwell.

Gardner, R. C. (1985). Social psychology and second language learning: The role of attitudes and motivation. London: Edward Arnold.

Gardner, R. C., \& Lambert, W. E. (1959). Motivational variables in second-language acquisition. Canadian Journal of Psychology, 13(4), 266-272.

Gardner, R. C., \& Lambert, W. E. (1972). Attitudes and motivation in second language learning. Rowley: Newbury House.

Guest, G., MacQueen, K. M., \& Namey, E. E. (2011). Applied thematic analysis. Thousand Oaks, California: Sage Publications.

Guilloteaux, M. J. (2013). Motivational strategies for the language classroom: Perceptions of Korean secondary school English teachers. System, 41(1), 3- 14.

Guilloteaux, M. J., \& Dörnyei, Z. (2008). Motivating language learners: A classroomoriented investigation of the effects of motivational strategies on student motivation. TESOL Quarterly, 42(1), 55-77.

Higgins, E. (1987). Self-discrepancy: A theory relating self and affect. Psychological Review, 94(3), 319-340.

Higgins, E. (1998). Promotion and prevention: Regulatory focus as a motivational principle. Advances in Experimental Social Psychology, 30(1), 1-46.

Islam, M., Lamb, M., \& Chambers, G. (2013). The L2 Motivational Self System and national interest: A Pakistani perspective. System, 41(2), 231-244.

Järvelä, S. (2001). Shifting research on motivation and cognition to an integrated approach on learning and motivation in context. In S. Volet \& S. Järvelä (Eds.), Motivation in learning contexts: Theoretical advances and methodological implications (pp. 3-14). Oxford: Pergamon.

Lamb, M. (2004). Integrative motivation in a globalizing world. System, 32(1), 3-19.

Lamb, M. (2012). A self system perspective on young adolescents' motivation to learn English in urban and rural settings. Language Learning, 62(4), 997-1023. 


\section{Ml Macrothink}

International Journal of English Language Education

ISSN 2325-0887

2017, Vol. 5, No. 2

Moskovsky, C., \& Alrabai, F. (2009). Intrinsic Motivation in Saudi Learners of English as a Foreign Language. The Open Applied Linguistics Journal, 2(1), 1-10. Retrieved from http://www.benthamscience.com/

Moskovsky, C., Alrabai, F., Paolini, S., \& Ratcheva, S. (2013). The effects of teachers' motivational strategies on learners' motivation: A controlled investigation of second language acquisition. Language Learning, 63(1), 34-62.

Noels, K. A., Clément, R., \& Pelletier, L. G. (1999). Perceptions of teacher communicative style and students' intrinsic and extrinsic motivation. Modern Language Journal, 83(1), 23-34.

Norton, B. (2000). Identity and language learning: Gender, ethnicity and educational change. Harlow: Longman.

Oxford, R. L., \& Shearin, J. (1994). Language learning motivation: Expanding the theoretical framework. The Modern Language Journal, 78(1), 12-28.

Pallant, J. (2010). SPSS survival manual: A step by step guide to data analysis using SPSS (4th ed.). Maidenhead: Open University Press.

Papi, M. (2010). The L2 motivational self system, L2 anxiety, and motivated behavior: A structural equation modeling approach. System, 38(3), 467-479.

Papi, M., \& Abdollahzadeh, E. (2012). Teacher motivational practice, student motivation, and possible L2 selves: An examination in the Iranian EFL context. Language Learning, 62(2), 571-592.

Ruesch, A., Bown, J., \& Dewey, D. P. (2012). Student and teacher perceptions of motivational strategies in the foreign language classroom. Innovation in Language Learning and Teaching, 6(1), 15-27.

Ryan, S. (2009). Self and identity in L2 motivation in Japan: the ideal L2 self and Japanese learners of English. In Z. Dörnyei \& E. Ushioda (Eds.), Motivation, language identity and the L2 self (pp. 120-143). Bristol: Multilingual Matters.

Stockwell, G. (2013). Technology and motivation in English-language teaching and learning. In E. Ushioda (Ed.), International perspectives on motivation, language learning and professional challenges (pp.156- 175). New York: Palgrave Macmillan.

Taguchi, T., Magid, M., \& Papi, M. (2009). The L2 motivational self system among Japanese, Chinese and Iranian learners of English: A comparative study. In Z. Dörnyei \& E. Ushioda (Eds.), Motivation, language identity and the L2 self (pp. 66-97). Bristol: Multilingual Matters.

Teddlie, C., \& Tashakkori, A. (2009). Foundations of mixed methods research: Integrating quantitative and qualitative approaches in the social and behavioral sciences. Thousand Oaks, California: Sage Publications.

Thompson, B. (2002). What future quantitative social science research could look like: 


\section{Macrothink}

Confidence intervals for effect sizes. Educational Researcher, 31(3), 25-32.

Ushioda, E. (1996). Developing a dynamic concept of motivation. In T. Hickey \& J. Williams (Eds.), Language, education and society in a changing world (pp. 239- 245). Clevedon: Multilingual Matters.

Ushioda, E. (2001). Language learning at university: Exploring the role of motivational thinking. In Z. Dörnyei \& R. Schmidt (Eds.), Motivation and second language acquisition (pp. 93-125). Honolulu: University of Hawaii Press.

Ushioda, E. (2009). A person-in-context relational view of emergent motivation, self and identity. In Z. Dörnyei \& E. Ushioda (Eds.), Motivation, language identity and the L2 self (pp. 215-228). Bristol: Multilingual Matters.

Ushioda, E. (2012). Motivation: L2 learning as a special case? In S. Mercer, S. Ryan \& M. Williams (Eds.), Psychology for language learning: Insights from research, theory and practice (pp. 58-73). Basingstoke, UK: Palgrave Macmillan.

Williams, M., \& Burden, R. (1997). Psychology for language teachers. Cambridge: Cambridge University Press.

Yashima, T. (2002). Willingness to communicate in a second language: The Japanese EFL Context. The Modern Language Journal, 86(1), 54-56. 


\section{Appendixes}

\section{Appendix 1: Exploratory interviews - Guidelines}

\section{- Teacher interview guidelines}

1. How can you describe your students' motivation in the English language classrooms?

2. Do you think it is important to use motivational strategies to develop students' motivation?

3. In your opinion what is the motivational strategies that should be used in language classroom?

4. At the beginning of the language class or task, how can you initiate your student's motivation?

5. How can you keep your student motivated during the classroom, or during a task?

6. At the end of the classroom or task, what strategies do you use to motivate your students?

7. Tell me about a motivated classroom, what you do to keep them motivated?

8. Now, tell me about a demotivated classroom, what do you do to encourage students' motivation?

9. What do you think are the most important motivational strategies, especially in the context of Saudi Arabia?

10. Do you have anything to add?

\section{- Student interview guidelines}

1. How can you describe your motivation in the English language classrooms?

2. Do you think EFL teachers should use motivational strategies to develop students' motivation?

3. In your opinion what is the motivational strategies that should be used in language classroom?

4. At the beginning of the language class or task, how can EFL teacher initiate students' motivation?

5. During English classroom or during doing a task, how can a teacher keep students motivated?

6. At the end of the classroom or task, what strategies do a teacher should use to motivate her students?

7. Tell me about a motivated teacher, what does she do to keep you motivated?

8. What do you think are the most important motivational strategies, especially in the context of Saudi Arabia?

9. Do you have anything to add? 


\section{Appendix 2: Teacher questionnaire (English version)}

\section{Universityof \\ Salford}

(Teacher Form)

Informed consent

The title of the study: Motivational strategies; the perceptions of EFL teachers and students in the Saudi higher education context (Teacher form)

Name: Eman Alshehri

You are invited to consider participating in this research study which examines teachers' and students' perceptions about some teaching practices which can motivate students, You will need to answer a questionnaire about your views regarding some teaching practices used to motivate students, It is not a test, so there are no "right" or "wrong" answers and you do not have to write your name. Please give your answer sincerely, only this will ensure the success of this study.

Your participation in this study is voluntary. If you decide to take part you are still free to withdraw at any time and without giving a reason.

Your participation will involve completing a questionnaire that will take approximately 20 minutes. Your responses will be confidential and we do not collect identifying information such as your name, email address. However, if you are willing to participate in the follow up interviews, you can write your contact details at the end of the questionnaire.

The questionnaire consists of three parts; the first part is about your perceptions about motivational teaching practices. The second section includes general questions (such as age, nationality) and the last part invites you to participate in the follow up interviews.

The information in the study records will be kept confidential. Data will be stored securely and will be made available only to researcher. You will not be asked to write your name in the questionnaire. By the end of the research, all questionnaires and interviews recordings will be destroyed. Your name or any contact details will not be written on the interview transcripts. In addition, any details which potentially could identify you will also be removed or changed.

The results of the study will be used in my PhD thesis. In addition, the results might be presented at academic conferences and in academic journals.

This study is a part of PhD thesis conducted at the University of Salford, UK and is sponsored by King Abdulaziz University as the researcher is a member of this university.

If you have any questions about the research study, please contact me at my email address e.alshehri@edu.salford.ac.uk

Researcher name; Eman Alshehri

* I have read the information about the study:

- Signature:

- Date: 


\section{Universityo
Salford}

(Teacher Form)

The perceptions of EFL teachers about motivational strategies (Teacher form)

\section{Part one: Teaching practices used to motivate students}

Following is a list of teaching practices which can be used by English teachers in classroom. Please choose an answer that best describes your level of agreement or disagreement with each practice in term of motivating your students to learn English. You can show your agreement by putting $(v)$ at the choice that best describe your level of agreement.

For example, If you disagree completely with the following statement, you should choose the 'strongly disagree' option.

\begin{tabular}{|c|c|c|c|c|c|c|}
\hline An English teacher should.................... & 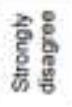 & 畩 & 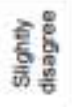 & 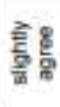 & 密 & 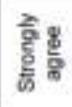 \\
\hline Do a quizz each week. & $\sqrt{ }$ & & & & & \\
\hline
\end{tabular}

An English teacher should.

1. Establish good relationship with students.

2. Offer ongoing feedback.

3. Allow students to get to know each other.

4. Show her enthusiasm for teaching English.

5. Offer rewards for participating in activities

6. Reduce students' language anxiety when they are speaking in English.

7. Bring in and encourage humour.

8. Invite senior students to share their English learning experiences with the class.

9. Allow students choices about the learning process.

10. Create a pleasant atmosphere in the classroom.

11. Avoid giving students the opportunity to socialise.

12. Provide students with positive feedback.

13 Help students accept the fact that they will make mistakes as part of the learning process.

14 Include activities that lead to the completion of whole group tasks, such as project work.

15. Show students how particular activities help them to attain their goal.

16 Encourage students to explore English community, like watching English TV channels.

17. Encourage students to imagine themselves using English when travelling abroad. 
University of

Salford

(Teacher Form)

An English teacher should.

Create a supportive classroom climate that allows students to make mistakes.

19. Teach her students self-motivating strategies, such as self

encouragement.

Select tasks which require students' movement in the classroom, such as role plays.

21. Make sure grades reflect students' effort.

22 Advise students to use English in the classroom rather than outside classroom.

23. Make tasks challenging.

24. Pay attention and listen to each student.

25. Use authentic materials, such as an article from an English newspaper.

26. Encourage students to try harder

27. Increase the amount of English she uses in the class.

28. Share the reasons for her interest in English with her students.

29. Invite successful role models to class.

30. Involve students in designing and running the English course

31. Be ready to answer academic questions of students.

32 Encourage students to imagine themselves using English to communicate with international friends.

33. Remind students of their duties to learn English.

34. Build the lesson plans based on students' needs.

35. Give students choices about how they will be assessed.

36. Draw students' attention to the content of the task.

37. Use learning technologies in her classes such as computer.

38 Indicate to her students that she believes in their efforts to learn English.

39. Offer rewards in a motivational manner.

40. Draw her students' attention to their strengths and abilities.

41. Provide face to face feedback to students about their progress. 
An English teacher should.

\begin{tabular}{|c|c|c|c|c|c|}
\hline 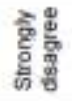 & 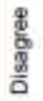 & 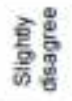 & 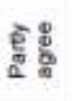 & $\frac{9}{2}$ & 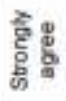 \\
\hline
\end{tabular}

42. Design tasks that are within the students' ability

43. Give students choices about when they will be assessed.

44. Be serious-minded in the classroom.

46. Show students that she cares about their progress.

46. Encourage group work.

47. Explain the purpose of a task.

48. Break the routine by varying the presentation format.

49. Help students develop realistic beliefs about their progress in English language learning.

50. Recognise students' academic progress.

51. Use small-group tasks where students can mix.

52. Present tasks in a motivated way.

53. Invite an English speaker to class.

54. Encourage students to set English learning goais.

56. Be the responsible about choosing the time of tests.

56. Remind students of the benefits of mastering English.

57 Encourage students to imagine the future situations where they will need English.

58. Celebrate students' success.

59. Encourage students to share personal experiences and thoughts.

60. Provide encouragement.

61. Use an interesting opening activity to start each class.

62. Relate the subject matter to the students' everyday experiences.

63. Organise outings:

64. State the objectives of each class.

65. Encourage students to imagine themselves using English in their future career. 
University of

Salford

(Teacher Form)

\section{Part two: General information}

Instruction: Please provide the following information by ticking $(\delta)$ in the box or writing your response in the space.

1. Age: $\quad \square 20-30 \quad \square 31-40 \quad \square 41-50 \quad \square 51-60 \quad \square$ Other, (Please specify)............

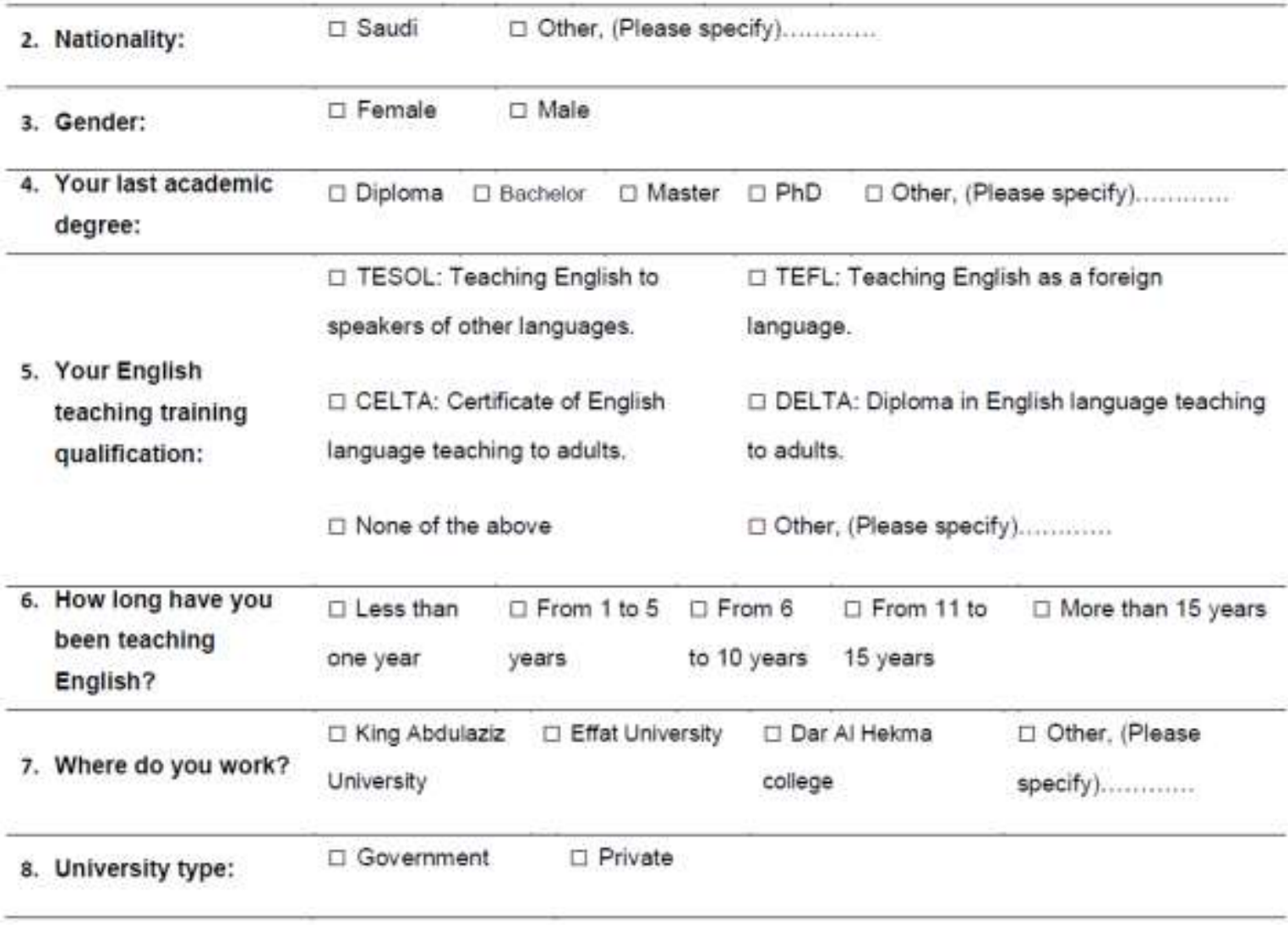

\section{Part three: Future interview}

Instruction: you are invited to participate in the follow up interviews which will be about the teaching practices that can be used to motivate students in English classrooms. The interview is very important for supporting the findings of the questionnaire, and you participation will add invaluable data to the study. The interview will be in Arabic, last around 30 minutes, and will be recorded.

If you would be willing to participate in the interview, please write the following information. Otherwise, you can leave it blank.

Name:

University or college:

Mobile number:

Email:

\section{Thank you for your participation (2)}




\title{
Appendix 3: Student questionnaire (English version)
}

\author{
Informed consent \\ The title of the study: Motivational strategies: the perceptions of EFL teachers and students in the Saudi higher \\ education context (Student form)
}

\section{Name: Eman Alshehri}

You are invited to consider participating in this research study which examines teachers' and students' perceptions about some teaching practices which can motivate students. You will need to answer a questionnaire about your views regarding the some teaching practices used to motivate students. It is not a test, so there are no "right" or "wrong" answers and you do not have to write your name. Please give your answer sincerely, only this will ensure the success of this study.

Your participation in this study is voluntary. If you decide to take part you are still free to withdraw at any time and without giving a reason. Choosing to either take part or not in the study will have no impact on your marks and assessments.

Your participation will involve completing a questionnaire that will take approximately 20 minutes. Your responses will be confidential and we do not collect identifying information such as your name, email address. However, if you are willing to participate in the follow up interviews, you can write your contact details at the end of the questionnaire.

The questionnaire consists of three parts; the first part is about your perceptions about motivational teaching practices. The second section includes general questions (such as age, nationality) and the last part invites you to participate in the follow up interviews.

The information in the study records will be kept confidential. Data will be stored securely and will be made available only to researcher. You will not be asked to write your name in the questionnaire. By the end of the research, all questionnaires and interviews recordings will be destroyed. Your name or any contact details will not be written on the interview transcripts. In addition, any details which potentially could identify you will also be removed or changed.

The results of the study will be used in my PhD thesis. In addition, the results might be presented at academic conferences and in academic journals.

This study is a part of PhD thesis conducted at the University of Salford, UK and is sponsored by King Abdulaziz University as the researcher is a member of this university.

If you have any questions about the research study, please contact me at my email address e.alshehri@edu.salford.ac.uk Researcher name: Eman Alshehri

* I have read the information about the study:

- Signature:

- Date: 


\section{Universityof \\ Salford}

(Student Form)

The perceptions of EFL students about motivational strategies (Student Form)

\section{Part one: Teaching practices used to motivate students}

Instruction: Following is a list of teaching practices which can be used by English teachers in classroom. Please choose an answer that best describes your level of agreement or disagreement with each practice in terms of motivating you to learn English. You can show your agreement by putting $(v)$ at the choice that best describe your level of agreement.

For example, If you disagree completely with the following statement, you should choose the 'strongly disagree' option.

An English teacher should

Do a quiz each week.

An English teacher should

1. Establish good relationship with students.

2. Offer ongoing feedback.

3. Allow students to get to know each other.

4. Show her enthusiasm for teaching English.

5. Offer rewards for participating in activities.

6. Reduce students' language anxiety when they are speaking in English.

7. Bring in and encourage humour.

8. Invite senior students to share their English learning experiences with 8. the class.

9. Allow students choices about the learning process.

10. Create a pleasant atmosphere in the classroom

11. Avoid giving students the opportunity to socialise.

12. Provide students with positive feedback.

13. Help students accept the fact that they will make mistakes as part of

the learning process.

14. Include activities that lead to the completion of whole group tasks, such

14. as project work.

15. Show students how particular activities help them to attain their goal.

16. Encourage students to explore English community, like watching

16. English TV channels.

17. Encourage students to imagine themselves using English when

travelling abroad. 
University of

Salford

(Student Form)

An English teacher should.

18. Create a supportive classroom climate that allows students to make mistakes.

19. Teach her students self-motivating strategies, such as self encouragement.

20. Select tasks which require students' movement in the classroom, such as role plays.

21. Make sure grades reflect students' effort.

22. Advise students to use English in the classroom rather than outside classroom.

23. Make tasks challenging.

24. Pay attention and listen to each student.

25. Use authentic materials, such as an article from an English newspaper.

26. Encourage students to try harder

27. Increase the amount of English she uses in the class.

28. Share the reasons for her interest in English with her students

29. Invite successful role models to class.

30. Involve students in designing and running the English course

31. Be ready to answer academic questions of students.

32. Encourage students to imagine themselves using English to communicate with international friends.

33. Remind students of their duties to learn English.

34. Build the lesson plans based on student's needs.

35. Give students choices about how they will be assessed.

36. Draw students' attention to the content of the task.

37. Use learning technologies in her classes such as computer.

38, Indicate to her students that she believes in their efforts to learn English.

39. Offer rewards in a motivational manner.

40. Draw her students' attention to their strengths and abilities.

41. Provide face to face feedback to students about their progress. 
An English teacher should

42. Design tasks that are within the students ability

43. Give students choices about when they will be assessed.

44. Be serious-minded in the classroom.

45. Show students that she cares about their progress.

46. Encourage group work.

47. Explain the purpose of a task.

48. Break the routine by varying the presentation format.

49. Help students develop realistic beliefs about their progress in English language learning

50. Recognise students' academic progress.

51. Use small-group tasks where students can mix.

52. Present tasks in a motivated way.

53. Invite an English speaker to class.

54. Encourage students to set English learning goals.

55. Be the responsible about choosing the time of tests.

56. Remind students of the benefits of mastering English.

57. Encourage students to imagine the future situations where they will need English.

58. Celebrate student's' success.

59. Encourage students to share personal experiences and thoughts

60. Provide encouragement.

61. Use an interesting opening activity to start each class.

62. Relate the subject matter to the students' everyday experiences.

63. Organise outings.

64. State the objectives of each class.

65. Encourage students to imagine themselves using English in their future career.

Page 3 of 4 


\section{Universityor}

(Student Form)

Part two: General information

Instruction: Please provide the following information by ticking $(v)$ in the box or writing your response in the space.

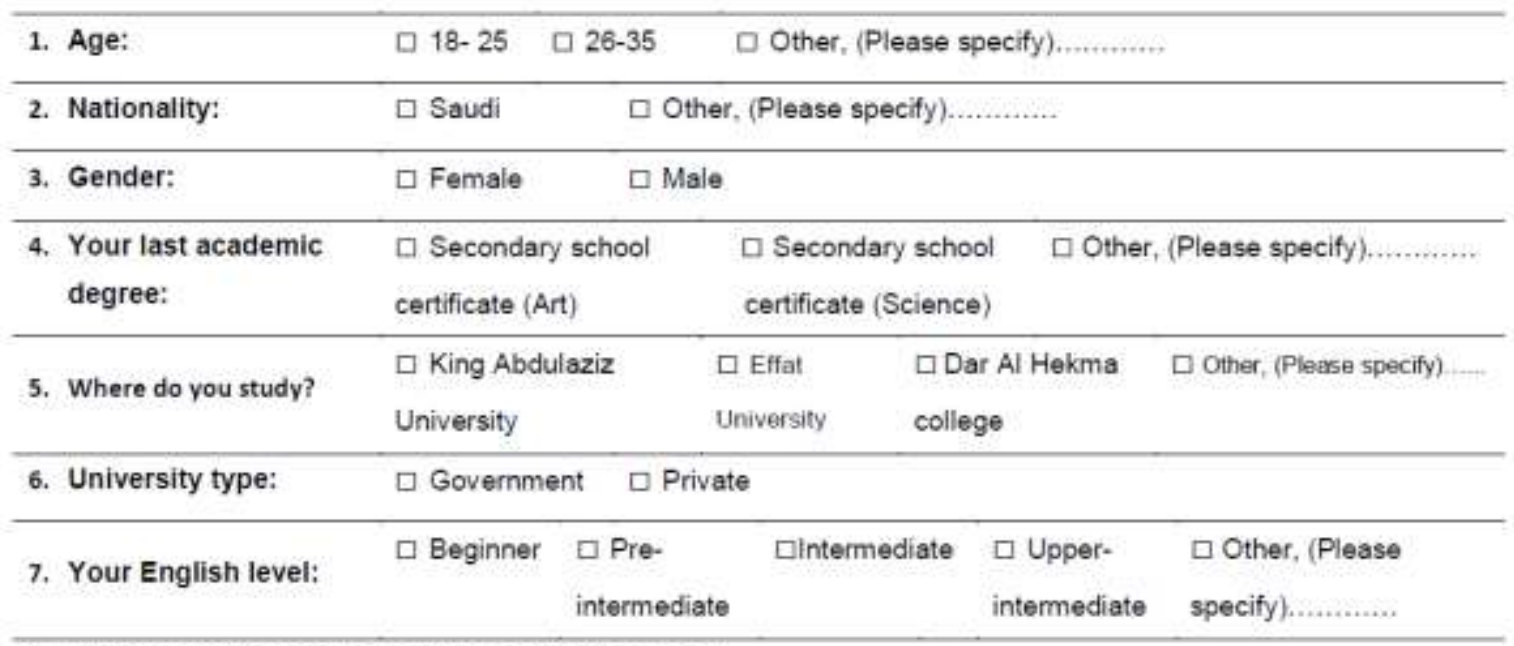

8. What is your score in the English language test?
$\square$ University placement test
IELTS.
D TOFEL
$\square$ Other, (Please specify)......

9. In which academic department are you planning to study?
$\square$ History
$\square$ Medicine
$\square$ Computer Sciences
$\square$ Arabic language
$\square$ Management
$\square$ Interior design
$\square$ Other, (Please specify).

10.1 your future academic department, in which you plan to study, taught in English?
$\square$ Yes
$\square$ No
ㅁI do not know

\section{Part three: Future interview}

Instruction: you are invited to participate in the follow up interviews which will be about the teaching practices that can be used to motivate students in English classrooms. The interview is very important for supporting the findings of the questionnaire, and you participation will add invaluable data to the study. The interview will be in Arabic, last around 30 minutes, and will be recorded.

If you would be willing to participate in the interview, please write the following information. Otherwise, you can leave it blank.

Name

University or college:

Mobile number:

Email 


\section{Appendix 4: Follow-up interview guidelines}

- Teachers:

1. How do you usually describe your students' motivation to learn English?

2. Tell me about the teaching practices you use when you want to motivate your strategies?

a. How do your students react to your motivating teaching practices?

b. Do you think these strategies motivate your students to learn English? Why?

3. What do you think are the most important and effective motivational strategies? Why?

4. Is there anything you want to add?

\section{- Students:}

1. How do you describe your motivation to study English?

2. Tell me about the teaching practices your teacher use to motivate students?

a. How do you react to these motivational teaching practices?

b. Do you think these strategies motivate you to learn English? Why?

3. What do you think are the most important and effective motivational strategies? Why?

4. Is there anything you want to add? 
Appendix 5: Internal reliability of the scales investigated in the study, with information for the subgroups (Teachers and students)

\begin{tabular}{|c|c|c|c|c|c|c|c|c|c|c|}
\hline \multirow[t]{2}{*}{ Scales } & \multirow[b]{2}{*}{$\begin{array}{l}\text { Items } \\
\text { no. }\end{array}$} & \multicolumn{3}{|c|}{ Whole sample } & \multicolumn{3}{|c|}{ Teachers } & \multicolumn{3}{|c|}{ Students } \\
\hline & & $\begin{array}{l}\text { Cases } \\
\text { no. }\end{array}$ & $\boldsymbol{\alpha}^{l}$ & $\begin{array}{l}\text { M } \\
\text { I-I } \\
\mathbf{C}^{2}\end{array}$ & $\begin{array}{l}\text { Cases } \\
\text { no. }\end{array}$ & $\alpha$ & $\begin{array}{l}\text { M } \\
\text { I-I } \\
\text { C }\end{array}$ & $\begin{array}{l}\text { Cases } \\
\text { no. }\end{array}$ & $\alpha$ & $\begin{array}{l}\text { M } \\
\text { I-I } \\
\text { C }\end{array}$ \\
\hline Ideal L2 self & 4 & 435 & 0.73 & 0.4 & 95 & 0.80 & 0.5 & 340 & 0.71 & 0.4 \\
\hline L2 related values & 6 & 420 & 0.68 & 0.3 & 92 & 0.75 & 0.3 & 328 & 0.67 & 0.3 \\
\hline Teacher behaviour & 6 & 422 & 0.65 & 0.2 & 90 & 0.68 & 0.3 & 332 & 0.62 & 0.2 \\
\hline Goals & 5 & 441 & 0.63 & 0.3 & 91 & 0.70 & 0.3 & 326 & 0.60 & 0.2 \\
\hline Learner autonomy & 5 & 422 & 0.71 & 0.3 & 91 & 0.76 & 0.4 & 331 & 0.58 & 0.2 \\
\hline Task & 5 & 429 & 0.68 & 0.3 & 94 & 0.72 & 0.4 & 335 & 0.65 & 0.3 \\
\hline Classroom atmosphere & 7 & 418 & 0.64 & 0.2 & 89 & 0.67 & 0.2 & 329 & 0.62 & 0.2 \\
\hline Learner confidence & 7 & 416 & 0.72 & 0.3 & 88 & 0.70 & 0.3 & 328 & 0.71 & 0.3 \\
\hline Learner group & 6 & 425 & 0.65 & 0.2 & 93 & 0.77 & 0.4 & 332 & 0.59 & 0.2 \\
\hline Recognise students' effort & 6 & 431 & 0.63 & 0.2 & 93 & 0.68 & 0.3 & 338 & 0.63 & 0.2 \\
\hline
\end{tabular}

Note: ${ }^{1}=$ Cronbach Alpha, ${ }^{2}=$ mean inter-item correlation. 


\section{Macrothink

\section{Copyright Disclaimer}

Copyright for this article is retained by the author(s), with first publication rights granted to the journal.

This is an open-access article distributed under the terms and conditions of the Creative Commons Attribution license (http://creativecommons.org/licenses/by/3.0/).

\footnotetext{
i The research was carried out within women's universities in Saudi Arabia due to restrictions on gender-mixing within this context.

${ }^{i i}$ Descriptive analysis of the questionnaire results considers central tendency response on scales for teacher and student groups. Since the data are not normally distributed, the study uses the median (Mdn) and interquartile range (IQR) to summarise the central tendency of the data (Field 2013; Connolly 2007). However, the mean and standard deviation (SD) are used to guide the organization of the data in tables, since the mean allows for some discrimination between scales, which is not always shown by the median scores.

iii (r37, TI-C2) means the source of the associated data was row 37 from the document entitled 'teacher interviews- coding 2).
} 